\title{
Calcium lactate as an attractive compound to partly replace salt in blue-veined cheese
}

\author{
Ecaterina Gore, ${ }^{1 *}$ Julie Mardon, ${ }^{2,3}$ Bord Cécile, ${ }^{2,3}$ and Annick Lebecque ${ }^{2,3}$ \\ ${ }^{1}$ Normandie University UNILEHAVRE, FR 3038 National Center for Scientific Research (CNRS), \\ Macromolecular and Organic Chemistry Research Unit (URCOM), F-76600 Le Havre, France \\ ${ }^{2}$ VetAgro Sup, 89 Avenue de l'Europe, 63370 Lempdes, France \\ ${ }^{3}$ Université Clermont Auvergne, INRA, Mixed Research Unit on Cheese (UMRF), F-15000 Aurillac, France
}

\section{ABSTRACT}

In addition to their high sodium content, cheeses are thought to induce an acid load to the body, which is associated with deleterious effects on consumers' health. Our objective was to explore the use of alkalinizing salts in partial substitution of $\mathrm{NaCl}$ to reduce both the sodium content and the acid-forming potential of cheese, without altering its sensory properties. Blue-veined cheeses were produced under industrial conditions, using brine salting followed by dry salting with a 4:1 (wt/ wt) mixture of calcium lactate: $\mathrm{NaCl}$ or calcium citrate: $\mathrm{NaCl}$. Sodium chloride was used in 2 granulometries: coarse (control treatment) and fine, to obtain homogeneous mixtures with the organic salts. Cheeses were then ripened for $56 \mathrm{~d}$. No major appearance defects were observed during ripening. Calcium lactate substitution decreased the Na content of the cheese core by $33 \%$, and calcium citrate substitution increased the citrate content of the cheese core by $410 \%$, respectively, compared with fine $\mathrm{NaCl}$. This study highlighted the substantial role of salt granulometry in sodium content, with the use of the coarse salt reducing the sodium content by $21 \%$ compared with fine salt. Sensory profiles showed nonsignificant differences in bitter and salty perceptions of salt-substituted cheeses with calcium lactate and calcium citrate compared with control cheeses. The use of calcium lactate should be considered to reduce the sodium content and improve the nutritional quality of cheeses while maintaining the sensory quality of the products. Alkalinizing organic salts could replace the acidifying salts $\mathrm{KCl}$ or $\mathrm{CaCl}_{2}$, which are currently used in salt replacement and are not recommended for consumers with renal disease. The method described here should be considered by cheese-making producers

Received May 3, 2018.

Accepted September 10, 2018.

*Corresponding author: ecaterina.gore@univ-lehavre.fr to improve the nutritional quality of cheese. Additional nutritional optimization strategies are suggested.

Key words: salt substitution, calcium lactate, calcium citrate, cheese, acid-forming potential

\section{INTRODUCTION}

Cheese is consumed in large quantities worldwide, both directly as table cheese and, increasingly, as an ingredient in recipes (Cruz et al., 2011; Bord et al., 2015). Besides its interesting nutritional properties (particularly as a strong contributor to calcium and protein supplies), cheese is one of the main food vectors of sodium and salt. In fact, $40 \mathrm{~g}$ of cheese containing $2 \%$ salt accounts for $16 \%$ of recommended daily sodium and salt intakes (WHO, 2013). Scientific data suggest that the effect of excess sodium on development of hypertension constitutes an important public health issue because hypertension is a recognized risk factor of cardiovascular diseases (He et al., 2011; Blaustein et al., 2012). In addition, a disregarded nutritional feature of cheese is its high acid-forming potential, as shown by its high mean potential renal acid load (PRAL) index (Gore et al., 2016a). The PRAL index takes into account the content of protein (the amount of sulfate produced from protein metabolism) and mineral composition (intestinal absorption, valence, or ionic charges of minerals; Remer and Manz, 1995), according to the following equation: PRAL $(\mathrm{mEq} / 100 \mathrm{~g}$ of edible portion $)=0.49 \times$ protein $(\mathrm{g} / 100 \mathrm{~g})+0.037 \times \mathrm{P}(\mathrm{mg} / 100$ g) $+0.027 \times \mathrm{Cl}(\mathrm{mg} / 100 \mathrm{~g})-0.041 \times \mathrm{Na}(\mathrm{mg} / 100 \mathrm{~g})$ $-0.021 \times \mathrm{K}(\mathrm{mg} / 100 \mathrm{~g})-0.026 \times \mathrm{Mg}(\mathrm{mg} / 100 \mathrm{~g})-$ $0.013 \times \mathrm{Ca}(\mathrm{mg} / 100 \mathrm{~g})$. Indeed, the consumption and metabolism of cheese leads to the production of fixed acids that induce an acid load to the body (Remer and Manz, 1995). In the long term, this state might induce deleterious effects on renal functions (Frassetto et al., 2007, 2008) as well as on bone and muscle tissues (Frassetto et al., 2008; Mardon et al., 2008; Pedone et al., 2010). As previously described, $\mathrm{Na}$ and $\mathrm{Cl}$ contents are 
important contributors to cheeses acid-forming potential (Gore et al., 2016a). Moreover, a high $\mathrm{NaCl}$ intake is recognized as an exacerbating factor of metabolic acidosis (Frassetto et al., 2007, 2008).

In the current situation, public health organizations recommend a gradual decrease of salt (sodium) intake of the population in the next years (WHO, 2013). One approach toward this goal is to reduce the salt content of foodstuffs that widely contribute to salt intake, including cheeses. For cheese, the main issue is how to decrease the $\mathrm{NaCl}$ content of cheese without altering its technological and sensory properties.

An alternative approach could be the partial replacement of $\mathrm{NaCl}$ by another compound that enhances salty perception. Salt substitution is an interesting practice widely reported to contribute to the decrease of salt intake by consumers (Cruz et al., 2011; Grummer et al., 2013; Lu and McMahon, 2015). Much research on $\mathrm{NaCl}$ substitution has explored the use of $\mathrm{CaCl}_{2}$, $\mathrm{KCl}$, or $\mathrm{MgCl}_{2}$ during the salting process. Descriptive sensory analyses demonstrated that treatments of both $\mathrm{NaCl}+\mathrm{CaCl}_{2}$ (with $45 \% \mathrm{Na}$ reduction) and $\mathrm{NaCl}+$ $\mathrm{MgCl}_{2}$ (with $53 \% \mathrm{Na}$ reduction) produced considerable off-flavors (bitter, metallic, and soapy) in Cheddar-type cheese (Grummer et al., 2012). The use of $\mathrm{KCl}$ as a salt substitute showed nonsignificant bitterness ratings at $54 \%$ and $60 \%$ Na reduction in Cheddar cheeses (Grummer et al., 2012, 2013). The use of 3:1 and 1:1 NaCl:KCl mixtures in Kefalograviera hard cheeses had no adverse effect on the quality of cheeses (Katsiari and Voutsinas, 1998). Conversely, after testing a $\mathrm{NaCl}$ substitution with $\mathrm{KCl}$ at 25, 50 and $75 \%$ in Minas cheeses, only the $25 \%$ level of substitution was judged acceptable to consumers because of the bitter-metallic aftertaste the $\mathrm{KCl}$ salt provides (Gomes et al., 2011).

Decreasing $\mathrm{NaCl}$ content in cheese would also contribute to reduce its acid-forming potential because the salting process has been identified as one of the main key steps responsible for this characteristic (Gore et al., 2016b). Nevertheless, $\mathrm{CaCl}_{2}, \mathrm{KCl}$, and $\mathrm{MgCl}_{2}$ salts are all acid-forming compounds (Remer, 2001). Furthermore, because of hyperkalemia risks, KCl-substituted products should be consumed with caution by consumers with renal disease (Berthet, 2009); for instance, the number of people affected by renal diseases $(10 \%$; Couchoud et al., 2015) would increase $2 \%$ per year. Thus, the use of alternative compounds, targeting the decrease in both $\mathrm{NaCl}$ content and the acid-forming potential of cheese would be of great interest from a nutritional point of view.

In the present study, we investigated the use of calcium organic salts (calcium lactate and calcium citrate) as partial substitutes for salt in a blue-veined cheese, which was identified in a previous study as having the highest salt content and PRAL value among all cheeses studied (Gore et al., 2016a), and comparable to Parmesan, which has been identified as the most acidifying cheese (Remer and Manz, 1995). The ingestion and metabolism of organic salts leads to the production of bicarbonate, a strong alkalinizing component in the body (Oh, 2000; Poupin et al., 2012). The use of calcium salts rubbed onto the outside of the cheese could also help to counterbalance the loss of alkaline minerals $(\mathrm{Ca}, \mathrm{Na}, \mathrm{K})$ from milk in the whey, during the cheese-making process, as draining was identified as one of the main steps responsible for the generation of the acid-forming potential of cheeses (Gore et al., 2016b). To date, calcium lactate and calcium citrate salts have been used for Ca enrichment (Cáceres et al., 2006; Selgas et al., 2009) and partial salt replacement in meat products (Riera et al., 1996). Organic salts such as potassium lactate are reported to effectively inhibit pathogenic flora and to enhance the salty perception in meat products at a substitution level of $30 \%$ (Astruc et al., 2008; Choi et al., 2014). Calcium lactate and calcium citrate salts have been used to enrich calcium levels in milk (39\%) and yogurt (36\%) (Singh et al., 2007; Singh and Muthukumarappan, 2008; Lacroix et al., 2013). In cheese, a previous study showed that calcium lactate did not sufficiently reproduce the salty taste in cream cheese and was insufficient for curing cheese at 12.8\% (Da Silva et al., 2013). It is noteworthy that salt substitution has not been previously investigated in blue cheese.

The objective of this work was to investigate the relevance of using calcium citrate and calcium lactate in partial substitute of salt to reduce both the $\mathrm{Na}$ content and the acid-forming potential of cheese. Nutritional and sensory implications of such substitutions were investigated in a soft blue-veined cheese manufactured on an industrial scale.

\section{MATERIALS AND METHODS}

\section{Cheese Manufacture}

Raw cow milk (30 t) was pasteurized $\left(72^{\circ} \mathrm{C}, 15 \mathrm{~s}\right)$ and standardized for fat content. A fermented cocktail (starter culture and Penicillium roqueforti, 0.6 L/100 L) was added as well as a rennet extract. The obtained coagulum was cut into cubes $(1 \times 2 \times 2 \mathrm{~cm})$ and a stirring process was applied to form grains of curd. The syneresis was carried out in molds to obtain drained curds (DC). The curds were brine salted (BSC) in a saturated $\mathrm{NaCl}$ solution at room temperature for 12 $\mathrm{h}$, and then manually salted once by rubbing 1 of the 
Table 1. Composition of salt mixes used for dry salting of blue-veined cheese (per $100 \mathrm{~g}$ of dry weight)

\begin{tabular}{|c|c|c|c|c|c|c|c|}
\hline Treatment $^{1}$ & $\begin{array}{c}\text { Proportion } \mathrm{Ca} \\
\text { salts/NaCl, } \\
\% \text { dry weight }\end{array}$ & $\begin{array}{c}\text { Granulometry, } \\
\mathrm{mm}\end{array}$ & \multicolumn{5}{|c|}{ Amount, ${ }^{2} \mathrm{~g} / 100 \mathrm{~g}$ of dry weight } \\
\hline Fine- $\mathrm{NaCl}$ & $0 / 100$ & $0-0.22$ & 39.3 & 60.7 & - & - & - \\
\hline CaLa & $75 / 25$ & $0-0.22$ & 9.8 & 15.2 & 13.7 & 61.3 & - \\
\hline $\mathrm{CaCi}$ & $75 / 25$ & $0-0.22$ & 9.8 & 15.2 & 18 & - & 57 \\
\hline
\end{tabular}

${ }^{1} \mathrm{Control}=$ cheese salted with coarse $\mathrm{NaCl}$ salt $(100 \%)$; fine- $\mathrm{NaCl}=$ cheese salted with fine-grain $\mathrm{NaCl}$ salt $(100 \%) ; \mathrm{CaLa}=$ cheese salted with a mix of calcium lactate $(75 \%)$ and fine-grain $\mathrm{NaCl}$ salt $(25 \%) ; \mathrm{CaCi}=$ cheese salted with a mix of calcium citrate $(75 \%)$ and fine-grain $\mathrm{NaCl}$ salt $(25 \%)$.

${ }^{2}$ Based on data provided by the manufacturers of the salts.

4 different treatments of dry salt on the surface of the cheese and pricking the cheeses to allow the growth of Penicillium roqueforti. Ripening was carried out over $56 \mathrm{~d}$.

\section{Substitution Salting Treatments}

The different substitution treatments were applied to BSC (as described above). Six cheese curds (2.2 kg each) per salt treatment were chosen randomly from a single batch of the industrial cheese-making process and submitted to 1 of the 4 salting treatments (Table $1)$. One salt treatment consisted of the standard industrial dry salting process, using dry coarse salt (0.9-3.15 $\mathrm{mm}$; control). To obtain homogeneous granulometry salt mixes with the Ca salts, which were commercially available in powdered form, fine-grain $\mathrm{NaCl}$ salt $(0-0.22$ mm granulometry) was used in the salt mixes and in a treatment designated "fine-NaCl." A 75\% substitution of dry fine $\mathrm{NaCl}$ was obtained with anhydrous calcium lactate (CaLa) and calcium citrate $(\mathbf{C a C i}$; Sigma Aldrich, Schnelldorf, Germany). The rate of substitution was determined in a preliminary study in which 4 different dry-salt substitution rates (from 25 to 100\%) were tested.

\section{Sampling}

The sampling plan is presented in Figure 1. At d $0,1 \mathrm{~L}$ of raw milk was sampled, packed in plastic vials, and rapidly frozen in a cooling cell (Tecnox/Rexel, Paris, France) to $-20^{\circ} \mathrm{C}$. On d 3,3 blocks of DC $(2.2$ $\mathrm{kg}$ each) per treatment were sampled and each block was cut into 6 portions in vertical cross-section; plastic bags containing 1 portion of $350 \mathrm{~g}$ from each of the 3 replicate blocks per treatment were vacuum-packed and frozen as described above. The same procedure was followed for BSC at d 4. Because the cheese does not have a rind at this stage, the whole portions of curd were ground to obtain a homogeneous mass before compositional analyses. Once ripening was complete (d $56), 3$ blocks of cheese ( $2.2 \mathrm{~kg}$ each) per salt treatment were sampled, as for DC, except that the rind (2-3 $\mathrm{mm}$ ) and core were separated. Although the rind of the cheese is consumable, most consumers prefer to remove it. Because this study concerned the application of different salting treatments on the surface of cheese, we considered it necessary to analyze the rind. To evaluate mineral migration and $\mathrm{pH}$ differences between the cheese core and rind, 1 block of cheese per salting treatment was sampled at $d 7,11$, and 19 of ripening. The removed core and rind $(2-3 \mathrm{~mm})$ were homogeneously ground and analyzed separately.

\section{Cheese Composition}

Samples were analyzed in triplicate according to International Organization for Standardization standards (AFNOR, 2013). The $\mathrm{pH}, \mathrm{DM}$, fat, ash, total $\mathrm{N}$, protein, chloride, minerals $(\mathrm{Ca}, \mathrm{K}, \mathrm{Na}, \mathrm{Mg}, \mathrm{P})$, and citrate and lactate contents were analyzed as described previously (Gore et al., 2016a,b).

\section{Sensory Analyses}

A panel of 10 assessors, from the external panel of VetAgro Sup's Engineering School (Lempdes, France), was selected and trained according to the guidelines in ISO 8586-1 (ISO, 2012). To describe cheeses, a sensory profile method was applied according to the recommendations of ISO 13299 (ISO, 2003). Before the evaluation sessions, training sessions were conducted, during which participants generated numerous attributes to describe blue cheeses. After statistical analysis, 29 attributes were finally selected: 11 attributes describing the rind and 18 the core (Table 2). Each attribute was associated with a definition, illustrated by food references and methods of assessment. Sensory evaluation 
was conducted in sensory computerized booths according to ISO 8589 (ISO, 2007).

Sensory analyses were carried out only on end products after $56 \mathrm{~d}$ of ripening. Quantitative descriptive analyses were performed on the cheese core and rind to evaluate appearance, texture, taste, odor, and aroma perceptions. For greater representativeness of the appearance of the cheeses (color, heterogeneity, moisture, blue vein quantity and distribution), one piece $(700 \mathrm{~g})$ of each whole cheese, presented in a vertical cross-section, was available to assessors at the time of the test. To evaluate odor, aroma, taste, and texture, individual cheese slice samples (30 g) and the removed rinds $(2-3 \mathrm{~mm})$ were presented on plastic plates coded with 3-digit random numbers. Samples were tempered and served at $20 \pm 1^{\circ} \mathrm{C}$, presented monadically, and distributed according to a Latin square design. Scoring was done using a 10-cm linear scale, anchored from 0 (very weak) to 10 (very intense), to record the intensity of the sensory attributes. Between each sample, assessors were asked to rinse their mouths successively with mineral water and unsalted crackers. Each cheese was evaluated in triplicate by each assessor. Scores were directly recorded on a computer system using Tastel software (version 2013, ABT Informatique, Rouvroysur-Marne, France).

\section{Statistical Analyses}

Statistical analyses of biochemical data were performed using the XLSTAT software package (Addinsoft, Paris, France); results are reported as means \pm standard deviations. One-way ANOVA and post-hoc multiple comparison (Tukey's test) were used to compare the studied elements. Differences between mean values were considered significant at $P<0.05$. Regarding the

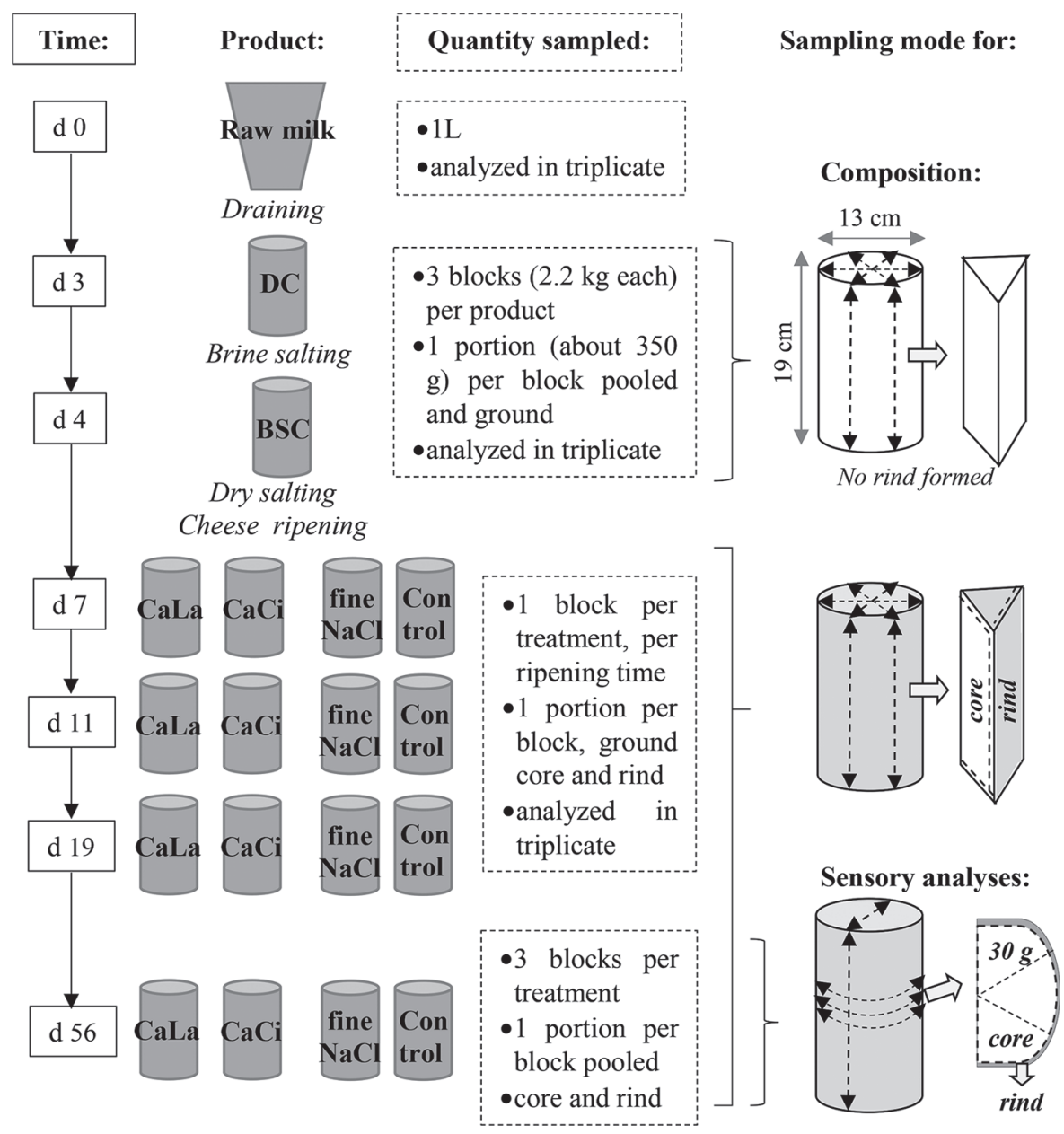

Figure 1. Sampling plan. $\mathrm{DC}=$ drained curd; $\mathrm{BSC}=$ brine-salted curd; Control = cheese salted with coarse $\mathrm{NaCl}$ salt $(100 \%)$; fine- $\mathrm{NaCl}=$ cheese salted with fine-grain $\mathrm{NaCl}$ salt $(100 \%)$; CaLa = cheese salted with a mix of calcium lactate (75\%) and fine-grain $\mathrm{NaCl}$ salt (25\%); CaCi $=$ cheese salted with a mix of calcium citrate $(75 \%)$ and fine-grain $\mathrm{NaCl}$ salt $(25 \%)$. 
sensory data analyses, a 2-way mixed-model ANOVA (product and assessor) with interaction was performed, with products being the fixed effect and assessors the random effect, at a 95\% confidence level. Tukey's test was used for multiple comparison tests on the product means, for each attribute, when means were considered different $(P<0.05)$.

\section{RESULTS AND DISCUSSION}

Cheeses are one of the main food vectors of sodium intake, ranking after condiments, sauces, and some meats (Chekri et al., 2012; Boisard et al., 2013), and cheese is the food group having the highest PRAL values (Remer and Manz, 1995), thus contributing to deleterious effects on consumer health (Frassetto et al., 2007; He et al., 2011; Blaustein et al., 2012). This work is the first to investigate the relevance of using calcium citrate and calcium lactate as partial substitutes of salt to reduce both $\mathrm{Na}$ content and the acid-forming potential of a soft blue-veined cheese.

\section{Effect of Brining and Salt Granulometry}

First, the drained curds of cheese were immerged in brine for the first step of salting. The composition anal-

Table 2. Sensory attributes and definition for the sensory profile of cheeses $(\mathrm{R}=$ rind; $\mathrm{C}=$ core $)$

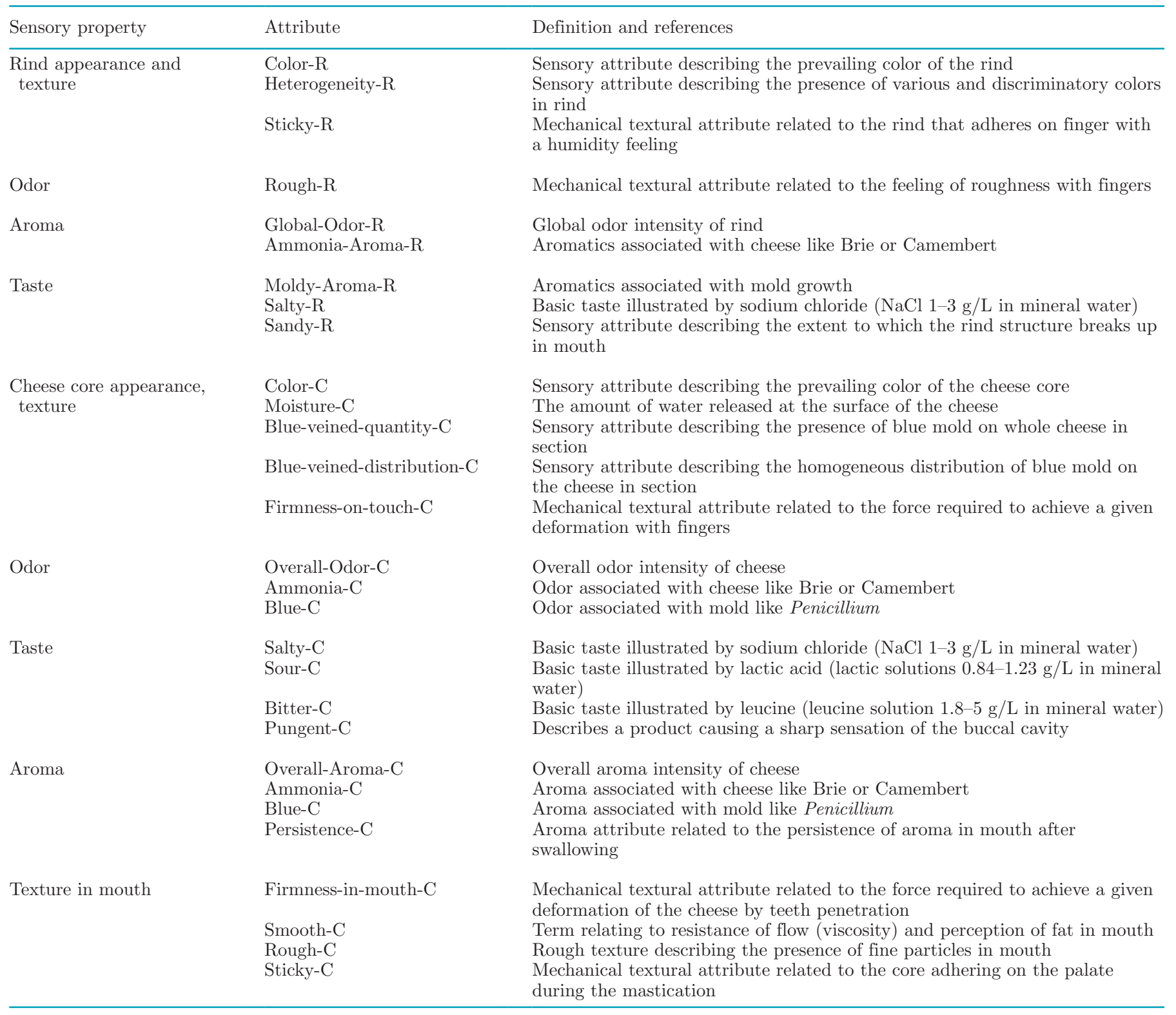


ysis (Table 3) showed that this first step contributed substantially to the $\mathrm{Na}$ and $\mathrm{Cl}$ contents of the cheese core: $45 \%$ total $\mathrm{Na}$ for the fine- $\mathrm{NaCl}$ treatment, $54 \%$ for control and $\mathrm{CaCi}$, and $67 \%$ for CaLa. The change of salt granulometry necessary to obtain homogeneous salt treatments induced an increase of almost $21 \%$ of $\mathrm{Na}$ in the fine- $\mathrm{NaCl}$ cheese core compared with the control core, reflecting greater penetration of $\mathrm{Na}$ in the cheese from fine-grain salt than from coarse salt (Table 3). Regarding the salt-substituted cheese cores, for the same granulometry and rate of substitution, lower $\mathrm{Na}$ and $\mathrm{Cl}$ penetration was detected for the CaLa treatment than the $\mathrm{CaCi}$ treatment. Both substituted cheeses differed (nonsignificantly) in Na content compared with control and fine- $\mathrm{NaCl}$ but showed a significant decrease $(P<$ 0.05) in $\mathrm{Cl}$ content. Similar nonstoichiometric relationships between $\mathrm{Cl}$ and $\mathrm{Na}$ were reported previously in Camembert and Cantal cheeses (Boutrou et al., 1999; Gaucheron et al., 1999; De Freitas et al., 2005, 2007), with greater variation in blue-veined cheese (Prieto et al., 2000, 2002; Gore et al., 2016a,b). In the literature, very few works have addressed the distribution of $\mathrm{Cl}$ and $\mathrm{Na}$ in the cheese matrix to understand this feature (Hardy, 1976, 1983; Boisard et al., 2013). The complex cheese matrix exerts a sieve effect on the diffusion of $\mathrm{Na}$ and $\mathrm{Cl}$ into cheese and water out of cheese, because the matrix consists of fat globules and protein aggregates that act as a barrier to $\mathrm{Na}$ ions and water movement (Guinee, 2004). Thus, salt and water will take other complex and lengthy paths to circumvent these barriers (Hardy, 1983; Ayyash, 2013). Brining and dry salting may result in uneven distribution of $\mathrm{Na}$ and $\mathrm{Cl}$ in cheese by creating zone variations in the cheese mass (Guinee et al., 2000; Ayyash, 2013). Zonal variations in the levels of salt occur within a cheese loaf immediately after salting and can persist for varying lengths of time afterward, depending on salting equipment and conditions, cheese structure, cheese composition, and storage conditions (Guinee, 2004; Ayyash, 2013).

\section{Effect of Organic Calcium Salt Substitution on Cheese Composition}

The mean values for $\mathrm{pH}$, DM, ash, total $\mathrm{N}$, fat, citrate, and lactate contents of the studied products are given in Table 4. Dry matter content was higher in the $\mathrm{CaCi}$ core compared with 3 other treatments. Correspondingly, $\mathrm{CaCi}$ cheeses were higher in fat and total $\mathrm{N}$ because of less dilution from moisture. The CaLa cheeses showed DM, total N, and fat contents comparable to the control cheese and to blue-veined cheeses from other studies (Bord et al., 2015; Jacquot et al., 2015; Gore et al., 2016a). In all cheeses, significantly higher ash content was reported in the rind

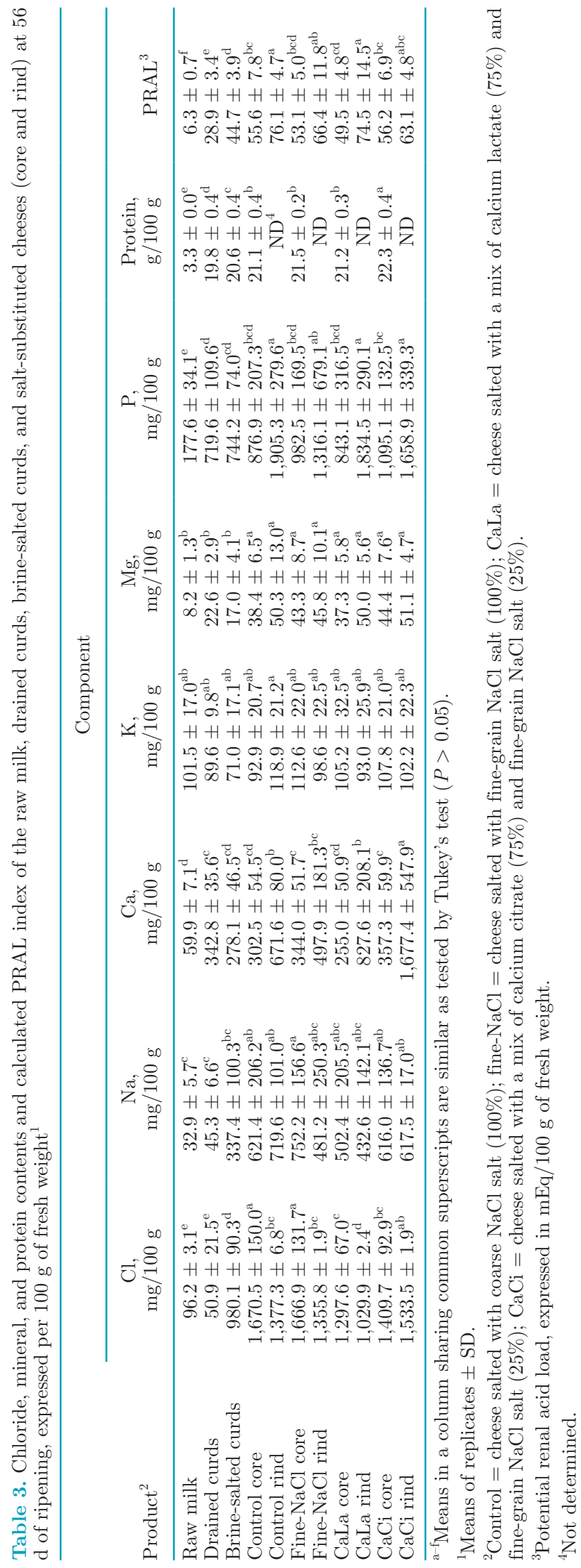


than in the core. As described by Morris et al. (1985), total mineral composition equilibrium between the rind and the cheese is not reached by d 56 of ripening. The ash content of the core in $\mathrm{CaCi}$, fine- $\mathrm{NaCl}$, and control cheeses was similar, and the CaLa cheese had the lowest ash content. In the rind, $\mathrm{CaLa}$, fine- $\mathrm{NaCl}$, and control cheeses had similar ash content but lower than that of $\mathrm{CaCi}$ cheese.

A pH gradient between the rind and core of the cheese was observed (Table 4; Figure 2a): at d 7, a difference of 0.1 to $0.2 \mathrm{pH}$ units was observed, which reached 0.2 to $0.3 \mathrm{pH}$ units in $4 \mathrm{~d}$. The largest $\mathrm{pH}$ gradient was formed between d 11 and 19, with a difference of 0.8 units in $\mathrm{pH}$ for control and 0.9 units for fine- $\mathrm{NaCl}$ and $\mathrm{CaCi}$. The most significant gradient was observed for CaLa cheese, with a 1.7-unit difference in $\mathrm{pH}$, comparable to that obtained in Camembert cheese at $15 \mathrm{~d}(2.5 \mathrm{pH}$ units; Abraham et al., 2007) and $20 \mathrm{~d}$ (2.1 pH units; Le Graet and Brulé, 1988) of ripening. It is also important to note that after $\mathrm{d} 19$, the $\mathrm{pH}$ difference between CaLa rind and core tended to decrease, with a slight decrease in the rind and an increase of $1.2 \mathrm{pH}$ units in the core. At d 56, the $\mathrm{pH}$ gradient slightly decreased for control and $\mathrm{CaCi}$ cheeses, by 0.7 and $0.6 \mathrm{pH}$ units, respectively. A smaller decrease of the $\mathrm{pH}$ gradient was observed for fine- $\mathrm{NaCl}(0.2 \mathrm{pH}$ units) and $\mathrm{CaLa}(0.4 \mathrm{pH}$ units) compared with 0.7 in Camembert at the end of the ripening (Abraham et al., 2007). The formation of the $\mathrm{pH}$ gradient may be comparable to that reported in Camembert cheese (McSweeney and Fox, 2004). Geotrichum candidum and Penicillium camemberti (P. roqueforti for blue-veined cheese) rapidly metabolize lactate into $\mathrm{CO}_{2}$ and $\mathrm{O}_{2}$, thus deacidifying the cheese surface. Deacidification causes a $\mathrm{pH}$ gradient to develop from the center of cheese to its surface. As surface $\mathrm{pH}$ increases, calcium phosphate precipitates as a layer of $\mathrm{Ca}_{3}\left(\mathrm{PO}_{4}\right)_{2}$, which causes an irreversible migration of calcium phosphate to the rind (Le Graet and Brulé, 1993; McSweeney and Fox, 2004; Abraham et al., 2007). The establishment of this gradient was probably accelerated by the addition of calcium lactate to the surface. The removal of rinds for analysis could explain the observed decrease of $\mathrm{Ca}$ content in the cheese core. This hypothesis was tested in this study by keeping and analyzing the rinds. In summary, CaLa cheeses showed a significant $(P<0.05)$ $\mathrm{pH}$ gradient and different behavior compared with the other 3 treatments.

The lactate and citrate contents in milk, DC, BSC, and cheeses at d 56 are presented in Table 4, and their evolution during ripening is given in Figure 2c and 2d. The CaLa cheese had a very high lactate content in the rind at $\mathrm{d} 7(5,195.1 \pm 259.3 \mathrm{mg} / 100 \mathrm{~g})$ because calcium lactate was added during the dry salting. The lactate content decreased gradually as ripening progressed, probably reflecting the surface flora activity and deacidification of the rind (McSweeney, 2004). The phenomenon of deacidification of the rind was observed after dry salting (d 3) until $72.2 \%$ of the lactate was metabolized (by d 19) and continued to decline until d 56 , with $87.4 \%$ loss of lactate in the rind. Conversely, the behavior of $\mathrm{CaCi}$ cheeses was very similar to that of fine- $\mathrm{NaCl}$ and control cheeses. No significant differ-

Table 4. Composition of the raw milk, drained unsalted curds, brine-salted curds, and cheeses (core and rind) at $56 \mathrm{~d}$ of ripening, expressed per $100 \mathrm{~g}$ of fresh weight ${ }^{1}$

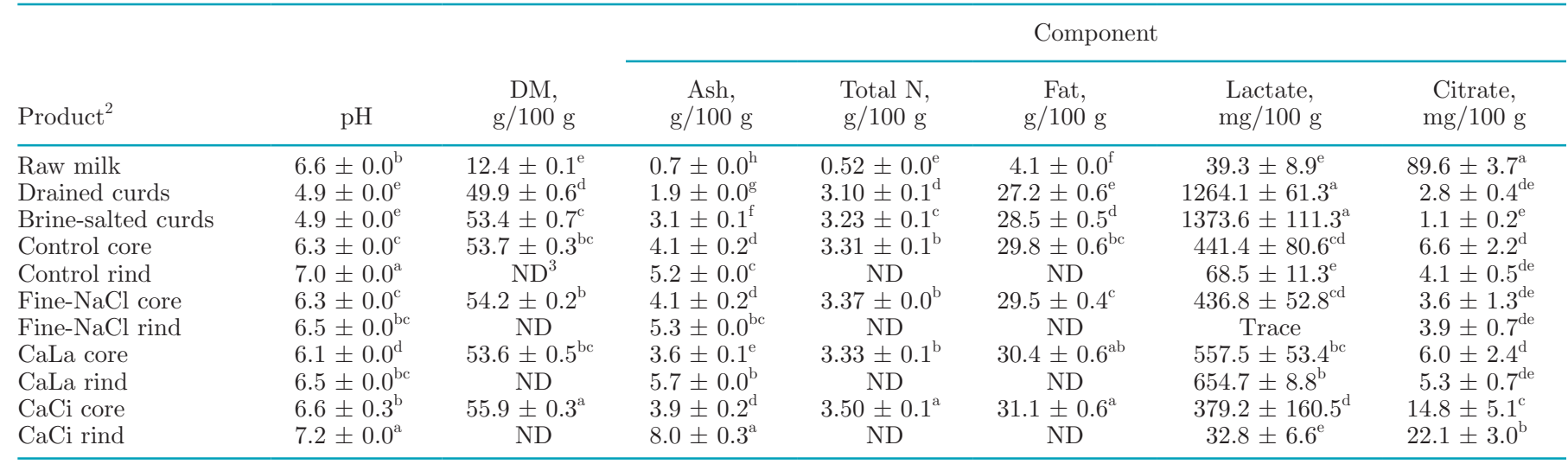

${ }^{\mathrm{a}-\mathrm{h}}$ Means in a column sharing common superscripts are similar as tested by Tukey's test $(P>0.05)$.

${ }^{1}$ Means of replicates $\pm \mathrm{SD}$.

${ }^{2} \mathrm{Control}=$ cheese salted with coarse $\mathrm{NaCl}$ salt $(100 \%)$; fine- $\mathrm{NaCl}=$ cheese salted with fine-grain $\mathrm{NaCl}$ salt $(100 \%)$; CaLa $=$ cheese salted with a mix of calcium lactate $(75 \%)$ and fine-grain $\mathrm{NaCl}$ salt $(25 \%) ; \mathrm{CaCi}=$ cheese salted with a mix of calcium citrate $(75 \%)$ and fine-grain $\mathrm{NaCl}$ salt $(25 \%)$.

${ }^{3}$ Not determined. 
ences in citrate content were observed between DC, $\mathrm{BSC}$, and the CaLa, fine- $\mathrm{NaCl}$, and control ripened cheeses. Changes in citrate contents were detected only in cheeses (core and rind) made with partial substitution of dry salt by calcium citrate. Conversely, citrate content did not reach the level found in raw milk (89.6 $\mathrm{mg} / 100 \mathrm{~g})$. The maximum level was reached at d 11 in the rind $(69.1 \mathrm{mg} / 100 \mathrm{~g})$. From that time onward, citrate content decreased significantly in the rind and increased slightly in the cheese core.

We also tested the hypothesis of migration of calcium phosphate to the rind under the effect of a $\mathrm{pH}$ gradient (Table 3; Figure 2a,b). First, calcium citrate is naturally richer in $\mathrm{Ca}$ than calcium lactate and provided much more $\mathrm{Ca}$ to the rind: calcium citrate provided $370 \%$ more $\mathrm{Ca}$ to the rind compared with the core and calcium lactate provided $225 \%$ more Ca at $\mathrm{d}$ 56. Second, the use of calcium citrate involves greater fluctuations in the Ca content of different salted cheeses, probably because of manual salting and cheese heterogeneity (Hardy, 1983; Abbas, 2012; Gore et al., 2016a). At all stages of ripening, more Ca was present in the rind of $\mathrm{CaCi}$ and more $\mathrm{Ca}$ was found in cheese, demonstrating that calcium citrate did not induced any notable $\mathrm{pH}$ gradient or, therefore, Ca migration. Thus, the $\mathrm{CaCi}$ cheese core was richer in $\mathrm{Ca}(\sim 100 \mathrm{mg} / 100 \mathrm{~g})$ compared with CaLa, but no significant difference was found for fine- $\mathrm{NaCl}$ or Control. For the CaLa treatment, the $\mathrm{Ca}$ content in cheese core increased on $\mathrm{d}$ 7 and then decreased after d 11, remaining relatively constant until late ripening (Figure $2 \mathrm{~b}$ ). Thus, we can hypothesize that $\mathrm{Ca}$ from calcium lactate migrated into the cheese in the first days of ripening, and then likely returned irreversibly to the rind under the action of the pH gradient (Le Graet et al., 1983; Le Graet and Brulé, 1988). Regarding $\mathrm{P}$ content, we found statistical differences in all cheese cores and rinds analyzed separately (Table 3). Conversely, significant differences $(P<0.05)$
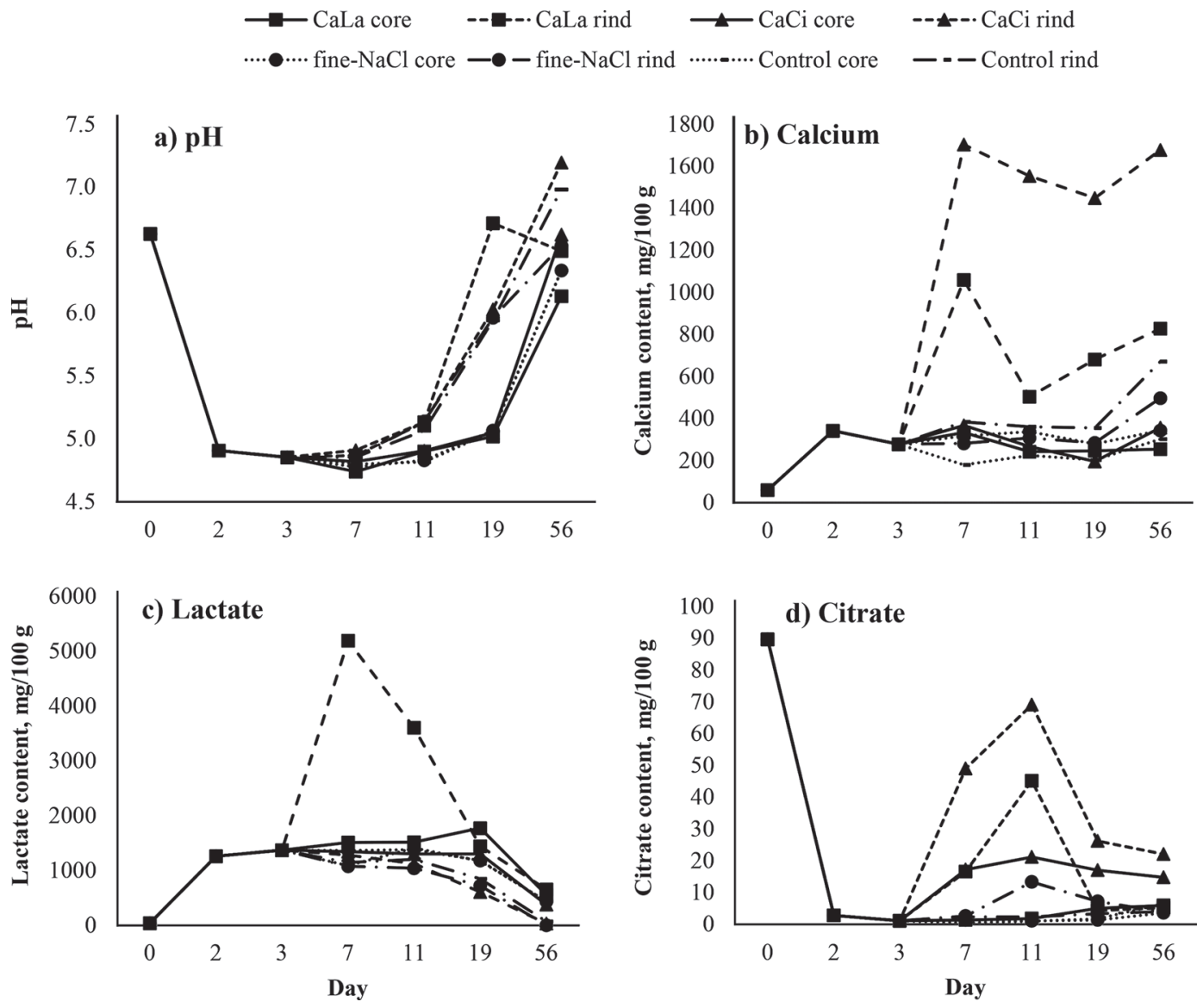

Figure 2. Evolution of (a) pH, (b) calcium, (c) lactate, and (d) citrate contents in 4 cheeses (core and rind) during manufacturing. Control $=$ cheese salted with coarse $\mathrm{NaCl}$ salt $(100 \%)$; fine- $\mathrm{NaCl}=$ cheese salted with fine-grain $\mathrm{NaCl}$ salt $(100 \%)$; CaLa $=$ cheese salted with a mix of calcium lactate $(75 \%)$ and fine-grain $\mathrm{NaCl}$ salt $(25 \%)$; $\mathrm{CaCi}=$ cheese salted with a mix of calcium citrate $(75 \%)$ and fine-grain $\mathrm{NaCl}$ salt $(25 \%)$. Day $0=$ raw milk; d $2=$ drained curd; d $3=$ brine-salted curd; d 7, 11, 19, and $56=$ cheeses at different ripening times. 
were detected between the cheese core and rind of the same cheese, with a higher content in the rind. Thus, we observed a difference in $\mathrm{P}$ content of almost $118 \%$ between the cheese core and rind for CaLa and control, whereas that of $\mathrm{CaCi}$ and fine- $\mathrm{NaCl}$ differed by 52 and $34 \%$, respectively, between core and rind. We can conclude that in all 4 blue-veined cheeses a lower $(\mathrm{CaCi}$, fine- $\mathrm{NaCl}$, and control) or higher (CaLa) $\mathrm{pH}$ gradient existed, and which induced lesser $\mathrm{Ca}$ and $\mathrm{P}$ migrations in $\mathrm{CaCi}$ and fine- $\mathrm{NaCl}$. In contrast, the $\mathrm{pH}$ gradient induced greater migration of $\mathrm{Ca}$ and $\mathrm{P}$ migrations in CaLa and control cheeses.

\section{Effect of Organic Calcium Salts on Acid-Forming Potential}

The PRAL elements (protein, $\mathrm{Ca}, \mathrm{K}, \mathrm{Mg}, \mathrm{P}, \mathrm{Na}$, and $\mathrm{Cl}$ ) and the calculated PRAL indexes of the products are shown in Table 3. Previous works already demonstrated the need to consider $\mathrm{Na}$ and $\mathrm{Cl}$ when calculating the PRAL index of processed foods (Gore et al., 2016a,b). The protein content of CaLa was comparable to that of fine- $\mathrm{NaCl}$ and control, whereas $\mathrm{CaCi}$ had a higher protein concentration, probably because of its higher DM content. Contents of $\mathrm{K}$ and $\mathrm{Mg}$ had little effect on acid-forming potential given their low concentrations in the ripened cheeses (Gore et al., 2016a) and the use of calcium lactate and calcium citrate did not affect their content in end products regardless of the treatment applied.

In the current study, the obtained PRAL indexes were almost twice $(55.6 \mathrm{mEq} / 100 \mathrm{~g})$ as high as the PRAL obtained in the same cheese in previous studies (28.0 mEq/100 g; Gore et al., 2016a,b). These results are related to the mineral content of raw milk and more specifically to its Ca:P ratio. In fact, milk from the current study was obtained in spring, at the time the herds were turned out to green grass pasture. The milk had a highly unbalanced Ca:P ratio (0.3), with a tripled $\mathrm{P}$ quantity and low Ca content compared with milk from other periods (ANSES, 2013), which affected the final composition of cheeses and therefore their PRAL. Reports in the literature argue that the mineral composition of the cheese is determined by the cheese-making process more than the milk compositional variability (Guéguen, 1997; Lucas et al., 2006a,b). However, some variations are reported for $\mathrm{Ca}$ and $\mathrm{P}$ levels in cow milk when cows are turned out to green grass pasture in spring (Guéguen, 1997). As stipulated by Notz (1997), milk is greater in $\mathrm{P}$ and reduced in $\mathrm{Ca}$ in this period, resulting a low Ca:P ratio. The results for $\mathrm{Ca}$ and $\mathrm{P}$ obtained in the blue-veined cheese in the current study were within the range given in the nutritional database CIQUAL (ANSES, 2013).

In the cheese core, none of the salt substitutions allowed significant PRAL optimization (Table 3), probably because of the high variabilities in the mineral composition discussed previously. The PRAL formula is often criticized for its limitations (Gore et al., 2016a,b), being generalized for all foodstuffs rather than specific to cheese. Moreover, alkalinizing anions are an important factor but they are not considered in the PRAL formula. Concerning the content of alkalinizing anions in the cheese core, CaLa substitution resulted in a nonsignificant increase in lactate content compared with control and fine- $\mathrm{NaCl}$, whereas the lactate content in the rind of CaLa was 10 times greater than that in control and fine- $\mathrm{NaCl}$. This interesting result should be considered when using calcium lactate as a salt substitute; it would be more relevant to add the calcium lactate to the milled curd before the molding step in order to enrich in these elements in the core and not the rind (which is not usually consumed). With the $\mathrm{CaCi}$ treatment, the citrate content of the cheese was increased by $224 \%$ compared with control and by $410 \%$ compared with fine-NaCl. Likewise, for better nutritional optimization, calcium citrate would be a good candidate for calcium fortification when added directly to the core, because the $\mathrm{Ca}$ content in the cheese rind was 5.5 times greater than in the core of the control cheese.

\section{Effect of Organic Calcium Salts Substitution on Sensory Properties}

A 2-way ANOVA (product, assessor) with interaction was applied to the sensory attributes (Table 5). The analyses showed a significant $(P<0.05)$ product effect for 13 sensory attributes from 29 total attributes $(45 \%)$. The product $\times$ assessor interaction was significant $(P<0.05)$ for only one sensory attribute (sandy; Table 5). These results are fundamental for subsequent analyses and interpretations because they demonstrate high reliability of the panel.

The salt-substituted cheeses were analyzed for significant sensory differences compared with the control cheeses (Table 5). The rind of the salt-substituted cheeses differentiated in color, texture (slightly sticky and sandy), and salty perceptions. The CaLa cheeses were characterized by a grayer color of rind (5.5) than $\mathrm{CaCi}$ and fine- $\mathrm{NaCl}$ cheeses, which was probably due to the metabolism of lactate by surface flora $G$. candi$d u m$ and $P$. roqueforti; lactate is a good substrate for these microorganisms (McSweeney, 2004; McSweeney 
and Fox, 2004). The sandy texture of the rind could be explained by the dry salting on the surface of cheeses and by the nature of the Ca salts (white powder and partly soluble). No significant $(P<0.05)$ differences were observed for heterogeneity, roughness, global odor, or ammonia and moldy aromas.

Cheese cores were differentiated by blue-vein quantity and distribution and firmness, whereas moisture and color were similar to those of the cheeses salted only with $\mathrm{NaCl}$ (coarse or fine). The $\mathrm{CaCi}$ cheese was characterized by greater blue-vein quantity (6.9) and better blue-vein distribution (7.0) than CaLa, but no significant differences with fine- $\mathrm{NaCl}$ were detected for these attributes. The CaLa cheese was judged as less firm to touch (3.6) than the 3 other treatments (4.3 average). No significant differences were observed for cheese odor (overall, ammonia, and blue). In the mouth, differences in pungent and blue aroma percep- tions were detected. The CaLa cheese had a less intense blue aroma (3.9) than control and was less pungent (2.4) than fine- $\mathrm{NaCl}$ and control cheeses. In addition, no significant differences in salty perception between the salt-substituted cheeses (6.7 and 6.9) and control (6.9) were detected, demonstrating their roles in enhancing the salty perception of products (Astruc et al., 2008; Choi et al., 2014). Notably, no significant effect on bitter taste was detected in either salt-substituted cheese. In agreement with the biochemical results, $\mathrm{CaCi}$ was firmer than CaLa, probably because of its higher DM content.

Overall, the sensory tests showed that a $75 \%$ reduction in dry $\mathrm{NaCl}$ is possible by substituting calcium lactate or calcium citrate without affecting salty and bitter tastes. The salt-substituted cheeses had appearance, texture, and aroma comparable to those of the control cheeses.

Table 5. Mean and standard deviation of sensory attribute intensity scores for blue-veined cheeses (core and rind) salted with different salt mixes

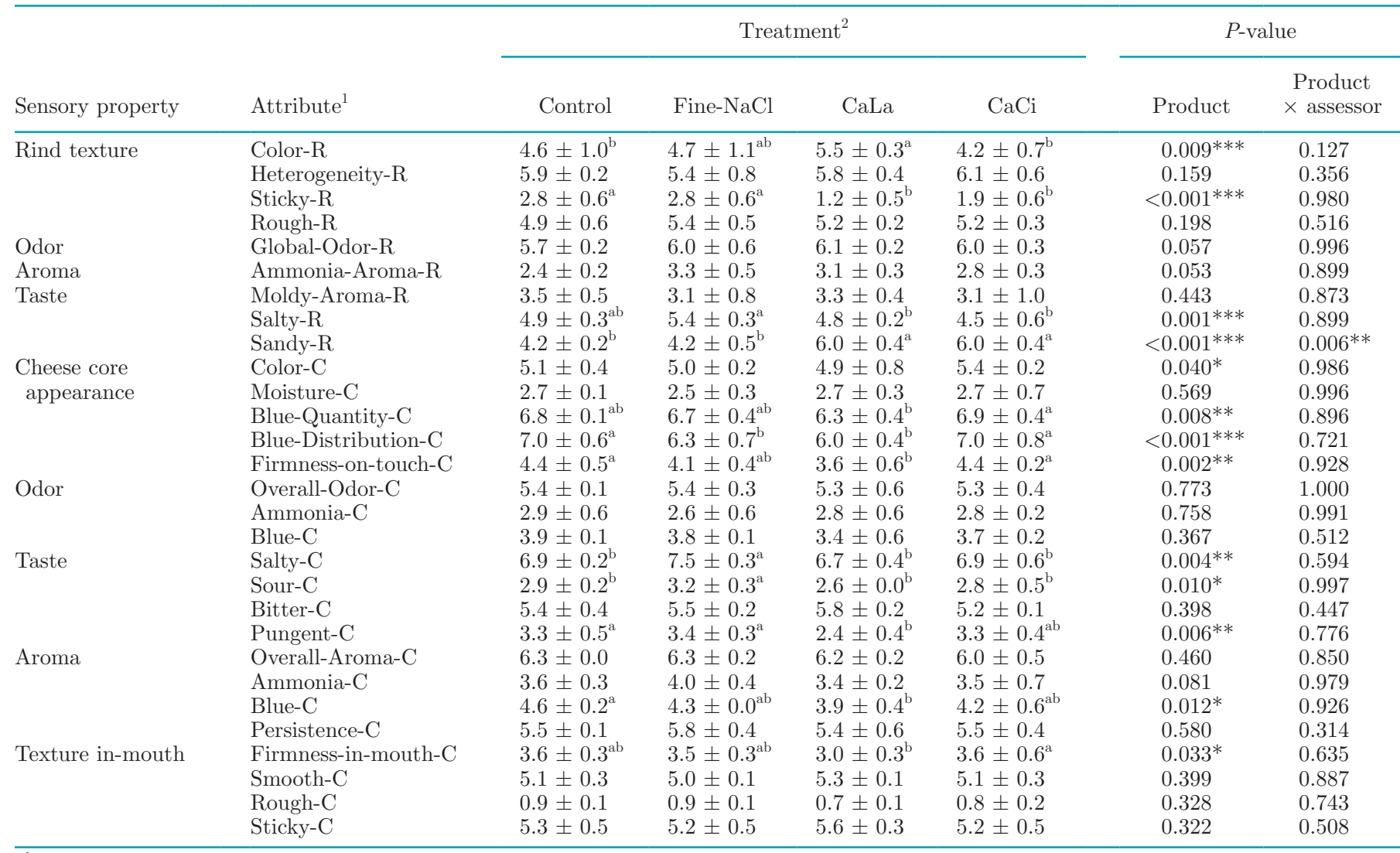

\footnotetext{
$\overline{\mathrm{a}, \mathrm{b}}$ Means within a row sharing common superscripts are not significantly different at $5 \%$ (Tukey's test).

${ }^{1} \mathrm{R}=$ rind; $\mathrm{C}=$ cheese core.

${ }^{2}$ Control $=$ cheese salted with coarse $\mathrm{NaCl}$ salt $(100 \%)$; fine- $\mathrm{NaCl}=$ cheese salted with fine-grain $\mathrm{NaCl}$ salt $(100 \%)$; CaLa = cheese salted with a mix of calcium lactate $(75 \%)$ and fine-grain $\mathrm{NaCl}$ salt $(25 \%)$; $\mathrm{CaCi}=$ cheese salted with a mix of calcium citrate $(75 \%)$ and fine-grain $\mathrm{NaCl}$ salt $(25 \%)$.

${ }^{*} P<0.05,{ }^{* *} P<0.01,{ }^{* * *} P<0.001$.
} 


\section{Implications}

The present study contributes interesting data that can assist in the nutritional optimization of cheese. Calcium lactate is an attractive compound for use in reducing the $\mathrm{Na}$ content in cheese. Both calcium lactate and calcium citrate would be excellent alternatives for $\mathrm{Ca}$ fortification if incorporated in the cheese mass after the milling of the curd, rather than by rubbing on the cheese surface. Our study showed that salt granulometry is a non-negligible factor that influences salt diffusion into the cheese matrix, thus significantly influencing $\mathrm{Na}$ content. Further research is necessary for a better understanding of this aspect. Based on this original work, further research is needed, especially to investigate whether replacement of the brining process by direct addition of organic salts to the milled curd before molding would be appropriate. The use of these salts in the milled curd of cheeses might result in a more homogeneous matrix and might yield more interesting results from a nutritional point of view. Moreover, the rapid metabolism of organic anions by surface flora would be avoided or at least reduced.

\section{CONCLUSIONS}

In this paper, we proposed a new method to reduce $\mathrm{Na}$ content by partly substituting $\mathrm{NaCl}$ with alkalinizing organic $\mathrm{Ca}$ salts. The blue-veined cheeses obtained using a $75 \%$ substitution of $\mathrm{NaCl}$ with calcium lactate contained about $33 \%$ less $\mathrm{Na}$ than the cheese salted only with fine $\mathrm{NaCl}$. Substitution with calcium citrate improved the citrate content by $410 \%$ compared with the fine- $\mathrm{NaCl}$ cheese. To improve $\mathrm{Ca}$ intake, consumption of the rind of the substituted cheeses is recommended. This study highlighted the substantial effect of salt granulometry on $\mathrm{Na}$ content, with the use of the coarse salt reducing the $\mathrm{Na}$ content by $21 \%$. The obtained products did not differ significantly in bitter or salty perception compared with the control cheese and could be considered of similar sensory quality. This approach improves the targeted nutritional properties of cheeses without altering their sensory properties and therefore should be considered by cheese-making producers.

\section{ACKNOWLEDGMENTS}

The research was co-financed FEDER (European Regional Development Funds) in Auvergne (France). The authors declared no potential conflicts of interest with respect to the research, authorship, or publication of this article.

\section{REFERENCES}

Abbas, K. 2012. Effet de traitements thermiques sur les propriétés fonctionnelles de fromages traditionnels: Le cas des pâtes persillées. PhD Thesis. Blaise Pascal University, Clermont-Ferrand, France.

Abraham, S., R. Cachon, B. Colas, G. Feron, and J. De Coninck. 2007. Eh and pH gradients in Camembert cheese during ripening: Measurements using microelectrodes and correlations with texture. Int. Dairy J. 17:954-960. https://doi.org/10.1016/j.idairyj 2006.12.010.

AFNOR. 2013. Association Française de Normalisation. Chemical Analysis. Accessed Nov. 9, 2015. http://sagaweb.afnor.org/fr-FR/ sw/Identification/AccueilAbonnement.

ANSES. 2013. Table de Composition Nutritionnelle Ciqual. Accessed Nov. 9, 2015. https://pro.anses.fr/TableCIQUAL/index.htm.

Astruc, T., R. Labas, J. L. Vendeuvre, J. L. Martin, and R. G. Taylor. 2008. Beef sausage structure affected by sodium chloride and potassium lactate. Meat Sci. 80:1092-1099. https://doi.org/10.1016/ j.meatsci.2008.05.007.

Ayyash, M. M. 2013. The effect of sodium chloride substitution with potassium chloride on chemical, physical and microbiological characteristics of Mediterranean cheeses. PhD Thesis. Victoria University, Melbourne, Australia.

Berthet, A. 2009. Nutrition et insuffisance rénale chronique. Thesis. Université Joseph Fourier, Grenoble, France.

Blaustein, M. P., F. H. H. Leenen, L. Chen, V. A. Golovina, J. M. Hamlyn, T. L. Pallone, J. W. V. Huysse, J. Zhang, and W. G. Wier. 2012. How $\mathrm{NaCl}$ raises blood pressure: a new paradigm for the pathogenesis of salt-dependent hypertension. Am. J. Physiol. Heart Circ. Physiol. 302:H1031-H1049. https://doi.org/10.1152/ ajpheart.00899.2011.

Boisard, L., I. Andriot, C. Arnould, C. Achilleos, C. Salles, and E. Guichard. 2013. Structure and composition of model cheeses influence sodium NMR mobility, kinetics of sodium release and sodium partition coefficients. Food Chem. 136:1070-1077. https://doi.org/ 10.1016/j.foodchem.2012.09.035.

Bord, C., D. Guerinon, and A. Lebecque. 2015. Impact of heating on sensory properties of French Protected Designation of Origin (PDO) blue cheeses. Relationships with physicochemical parameters. Food Sci. Technol. Int. 22:377-388. https://doi.org/10.1177/ 1082013215605201.

Boutrou, R., F. Gaucheron, M. Piot, F. Michel, J.-L. Maubois, and J. Léonil. 1999. Changes in the composition of juice expressed from Camembert cheese during ripening. Lait 79:503-513. https://doi .org/10.1051/lait:1999541.

Cáceres, E., M. L. García, and M. D. Selgas. 2006. Design of a new cooked meat sausage enriched with calcium. Meat Sci. 73:368-377. https://doi.org/10.1016/j.meatsci.2005.12.016.

Chekri, R., L. Noël, S. Millour, C. Vastel, A. Kadar, V. Sirot, J.-C. Leblanc, and T. Guérin. 2012. Calcium, magnesium, sodium and potassium levels in foodstuffs from the second French Total Diet Study. J. Food Compos. Anal. 25:97-107. https://doi.org/10.1016/ j.jfca.2011.10.005.

Choi, Y. M., K. C. Jung, H. M. Jo, K. W. Nam, J. H. Choe, M. S. Rhee, and B. C. Kim. 2014. Combined effects of potassium lactate and calcium ascorbate as sodium chloride substitutes on the physicochemical and sensory characteristics of low-sodium frankfurter sausage. Meat Sci. 96:21-25. https://doi.org/10.1016/j.meatsci 2013.06.022.

Couchoud, C., M. Lassalle, and C. Jacquelinet. 2015. REIN annual report 2015. Biomedecine Agency, Saint Denis la Plaine, France.

Cruz, A. G., J. A. F. Faria, M. A. R. Pollonio, H. M. A. Bolini, R. M. S. Celeghini, D. Granato, and N. P. Shah. 2011. Cheeses with reduced sodium content: Effects on functionality, public health benefits and sensory properties. Trends Food Sci. Technol. 22:276 291. https://doi.org/10.1016/j.tifs.2011.02.003.

Da Silva, T. L. T., V. R. De Souza, A. C. M. Pinheiro, C. A. Nunes, and T. V. M. Freire. 2013. Equivalence salting and temporal dominance of sensations analysis for different sodium chloride substi- 
tutes in cream cheese. Int. J. Dairy Technol. 67:31-38. https://doi .org/10.1111/1471-0307.12100.

De Freitas, I., N. Pinon, C. Lopez, and A. Thierry. 2005. Microstructure, physicochemistry, microbial populations and aroma compounds of ripened Cantal cheeses. Lait 85:453-468. https://doi .org/10.1051/lait.

De Freitas, I., N. Pinon, A. Thierry, and C. Lopez. 2007. In depth dynamic characterisation of French PDO Cantal cheese made from raw milk. Lait 87:97-117. https://doi.org/10.1051/lait.

Frassetto, L. A., and R. Morris Jr.., DSellmeyer, and ASebastian. 2008. Adverse effects of sodium chloride on bone in the aging human population resulting from habitual consumption of typical American diets. J. Nutr. 138:419S-422S.

Frassetto, L. A., S. A. Lanham-New, H. M. Macdonald, T. Remer, A. Sebastian, K. L. Tucker, and F. A. Tylavsky. 2007. Standardizing terminology for estimating the diet-dependent net acid load to the metabolic system. J. Nutr. 137:1491-1492.

Gaucheron, F., Y. Le Graët, F. Michel, V. Briard, and M. Piot. 1999 Evolution of various salt concentrations in the moisture and in the outer layer and centre of a model cheese during its brining and storage in an ammoniacal atmosphere. Lait 79:553-566.

Gomes, A. P., A. G. Cruz, R. S. Cadena, R. M. S. Celeghini, J. A. F. Faria, H. M. A. Bolini, M. A. R. Pollonio, and D. Granato. 2011. Manufacture of low-sodium Minas fresh cheese: Effect of the partial replacement of sodium chloride with potassium chloride. J. Dairy Sci. 94:2701-2706. https://doi.org/10.3168/jds.2010-3774.

Gore, E., J. Mardon, D. Guerinon, and A. Lebecque. 2016a. Exploratory study of acid-forming potential of commercial cheeses: impact of cheese type. Int. J. Food Sci. Nutr. 67:412-421. https://doi .org/10.3109/09637486.2016.1166188.

Gore, E., J. Mardon, and A. Lebecque. 2016b. Draining and salting as responsible key steps in the generation of the acid-forming potential of cheese: Application to a soft blue-veined cheese. J. Dairy Sci. 99:6927-6936. https://doi.org/10.3168/jds.2016-11094.

Grummer, J., N. Bobowski, M. Karalus, Z. Vickers, and T. Schoenfuss. 2013. Use of potassium chloride and flavor enhancers in low sodium Cheddar cheese. J. Dairy Sci. 96:1401-1418. https://doi .org $/ 10.3168 /$ jds.2012-6057.

Grummer, J., M. Karalus, K. Zhang, Z. Vickers, and T. C. Schoenfuss. 2012. Manufacture of reduced-sodium Cheddar-style cheese with mineral salt replacers. J. Dairy Sci. 95:2830-2839. https://doi.org/ 10.3168/jds.2011-4851.

Guéguen, L. 1997. La Valeur Nutritionnelle Minérale du Lait de Chèvre. Editions Quae, Niort, France.

Guinee, T. P. 2004. Salting and the role of salt in cheese. Int. J. Dairy Technol. 57:99-109. https://doi.org/10.1111/j.1471-0307 2004.00145.x.

Guinee, T. P., E. O. Mulholland, C. Mullins, and M. O. Corcoran 2000. Effect of salting method on the composition, yield and functionality of low moisture Mozzarella cheese. Milchwissenschaft $55: 135-138$.

Hardy, J. 1976. Etude de la duffusion du sel dans les fromages à pate molle de type Camembert. Comparaison du salage à sec et du salage en saumure. PhD Thesis. Université de Nancy, Nancy, France.

Hardy, J. 1983. Diffusion et distribution du chlorure de sodium dans les fromages. Influence sur l'activité de l'eau et les propriétés de sorption de l'eau. PhD Thesis. Institut National Polytechnique de Lorraine, Nancy, France.

He, F. J., M. Burnier, and G. A. MacGregor. 2011. Nutrition in cardiovascular disease: salt in hypertension and heart failure. Eur. Heart J. 32:3073-3080. https://doi.org/10.1093/eurheartj/ehr194.

ISO. 2003. ISO 13299:2003. Sensory analysis-Methodology: General guidance for establishing a sensory profile. International Organization for Standardization (ISO), Geneva, Switzerland.

ISO. 2007. ISO 8589:2007. Sensory analysis - General guidance for the design of test rooms. International Organization for Standardization (ISO), Geneva, Switzerland.

ISO. 2012. ISO 8586-1:2012. Sensory analysis - General guidelines for the selection, training and monitoring of selected assessors and expert sensory assessors. International Organization for Standardization (ISO), Geneva, Switzerland.
Jacquot, S., R. Karoui, K. Abbas, A. Lebecque, C. Bord, and A. AitKaddour. 2015. Potential of multispectral imager to characterize anisotropic French PDO cheeses: A feasibility study. Int. J. Food Prop. 18:213-230. https://doi.org/10.1080/10942912.2013.828746.

Katsiari, M., and L. P. Voutsinas. 1998. Manufacture of Kefalograviera cheese with less sodium by partial replacement of $\mathrm{NaCl}$ with KCl. Food Chem. 61:63-70. https://doi.org/10.1016/S0308 -8146(97)00113-1.

Lacroix, M., J. Han, M. Britten, C. P. Champagne, and P. Fustier. 2013. Cheese fortification. Pages 71-86 in Handbook of Food Fortification and Health. V. R. Preedy, R. Srirajaskanthan, and V. B. Patel, ed. Nutrition and Health. Springer, New York, NY.

Le Graet, Y., and G. Brulé. 1988. Migration des macro et oligo-éléments dans un fromage à pâte molle de type Camembert. Lait 68:219-234. https://doi.org/10.1051/lait:1988215.

Le Graet, Y., and G. Brule. 1993. Effects of $\mathrm{pH}$ and ionic strength on distribution of mineral salts in milk. Lait 73:51-60. https://doi .org/10.1051/lait:199312.

Le Graet, Y., A. Lepienne, G. Brulé, and P. Ducruet. 1983. Migration du calcium et des phosphates inorganiques dans les fromages à pâte molle de type Camembert au cours de l'affinage. Lait 63:317332. https://doi.org/10.1051/lait:1983629-63019.

Lu, Y., and D. J. McMahon. 2015. Effects of sodium chloride salting and substitution with potassium chloride on whey expulsion of Cheddar cheese. J. Dairy Sci. 98:78-88. https://doi.org/10.3168/ jds.2014-8600.

Lucas, A., S. Hulin, V. Michel, C. Agabriel, J.-F. Chamba, E. Rock, and J. B. Coulon. 2006a. Relations entre les conditions de production du lait et les teneurs en composés d'intérêt nutritionnel dans le fromage: Étude en conditions réelles de production. INRA Prod. Anim. 19:15-28.

Lucas, A., E. Rock, J. Chamba, I. Verdier-Metz, P. Brachet, and J. B. Coulon. 2006b. Respective effects of milk composition and the cheese-making process on cheese compositional variability in components of nutritional interest. Lait 86:21-41.

Mardon, J., V. Habauzit, A. Trzeciakiewicz, M.-J. Davicco, P. Lebecque, S. Mercier, J.-C. Tressol, M.-N. Horcajada, C. Demigné, and V. Coxam. 2008. Long-term intake of a high-protein diet with or without potassium citrate modulates acid-base metabolism, but not bone status, in male rats. J. Nutr. 138:718-724.

McSweeney, P. L. H. 2004. Biochemistry of cheese ripening. Int. J. Dairy Technol. 57:127-144. https://doi.org/10.1111/j.1471-0307 2004.00147.x.

McSweeney, P. L. H., and P. F. Fox. 2004. Metabolism of residual lactose and of lactate and citrate. Pages 361-371 in Cheese: Chemistry, Physics and Microbiology. P. F. Fox, P. McSweeney, T. Cogan, and T. Guinee, ed. Elsevier Academic Press, San Diego, CA.

Morris, H. A., T. P. Guinee, and P. F. Fox. 1985. Salt diffusion in Cheddar cheese. J. Dairy Sci. 68:1851-1858. https://doi.org/10 .3168/jds.S0022-0302(85)81041-9.

Notz, E. 1997. Etat Des Connaissances Concernant l'affinage et La Maîtrise de La Qualité Des Fromages à Pâte Pressée Cuite. Tome 1. Les Facteurs Intervenant Sur Les Aptitudes à La Conservation Des Fromages Avant l'affinage. ITG, Poligny, France.

Oh, M. S. 2000. New perspectives on acid-base balance. Semin. Dial. 13:212-219. https://doi.org/10.1046/j.1525-139x.2000.00061.x.

Pedone, C., N. Napoli, P. Pozzilli, F. Lauretani, S. Bandinelli, L. Ferrucci, and R. Antonelli-Incalzi. 2010. Quality of diet and potential renal acid load as risk factors for reduced bone density in elderly women. Bone 46:1063-1067. https://doi.org/10.1016/j.bone.2009 .11 .031 .

Poupin, N., J. Calvez, C. Lassale, C. Chesneau, and D. Tomé. 2012. Impact of the diet on net endogenous acid production and acidbase balance. Clin. Nutr. 31:313-321. https://doi.org/10.1016/j .clnu.2012.01.006.

Prieto, B., I. Franco, J. M. Fresno, A. Bernardo, and J. Carballo. 2000. Picón Bejes-Tresviso blue cheese: an overall biochemical survey throughout the ripening process. Int. Dairy J. 10:159-167. https:/ /doi.org/10.1016/S0958-6946(00)00032-7.

Prieto, B., I. Franco, J. G. Prieto, A. Bernardo, and J. Carballo. 2002. Compositional and physico-chemical modifications during the 
manufacture and ripening of León raw cow's milk cheese. J. Food Compos. Anal. 15:725-735. https://doi.org/10.1006/jfca.2002 .1055 .

Remer, T. 2001. Influence of nutrition on acid-base balance-Metabolic aspects. Eur. J. Nutr. 40:214-220.

Remer, T., and F. Manz. 1995. Potential renal acid load of foods and its influence on urine pH. J. Am. Diet. Assoc. 95:791-797. https:/ /doi.org/10.1016/S0002-8223(95)00219-7.

Riera, J. B., M. R. Martinez, R. C. Salcedo, G. M. Juncosa, and J. C. Sellart. 1996. Process for producing a low sodium meat product. Classification aux États-Unis 426/266, 426/641, 426/281, 426/646, 426/412, 426/407; Classification internationale A23L13/70, A23B4/027; Classification coopérative A23L1/3182, A23B4/027; Classification européenne A23L1/318B, A23B4/027, assignee. US Pat. No. 5534279.

Selgas, M. D., P. Salazar, and M. L. García. 2009. Usefulness of calcium lactate, citrate and gluconate for calcium enrichment of dry fermented sausages. Meat Sci. 82:478-480. https://doi.org/10 .1016/j.meatsci.2009.04.001.

Singh, G., S. Arora, G. S. Sharma, J. S. Sindhu, V. K. Kansal, and R. B. Sangwan. 2007. Heat stability and calcium bioavailability of calcium-fortified milk. Lebensm. Wiss. Technol. 40:625-631. https: //doi.org/10.1016/j.lwt.2006.03.009.

Singh, G., and K. Muthukumarappan. 2008. Influence of calcium fortification on sensory, physical and rheological characteristics of fruit yogurt. Lebensm. Wiss. Technol. 41:1145-1152. https://doi.org/10 $.1016 /$ j.lwt.2007.08.027.

WHO. 2013. Salt reduction and iodine fortification strategies in public health. World Health Organization, Geneva, Switzerland. http://apps.who.int/iris/bitstream/handle/10665/101509/ 9789241506694_eng.pdf?ua=1. 